\title{
Determinan Abortus di Indonesia
}

\author{
Titik Kuntari*, Siswanto Agus Wilopo**, Ova Emilia**
}

\begin{abstract}
Abstrak
Abortus menjadi masalah yang penting dalam kesehatan masyarakat karena berpengaruh terhadap morbiditas dan mortalitas maternal. Di Indonesia, belum ada data yang komprehensif tentang kejadian abortus, berbagai data yang ada sebelumnya berdasarkan survei dengan cakupan yang relatif terbatas. Abortus yang tidak aman bertanggung jawab terhadap $11 \%$ kematian ibu di Indonesia. Penelitian ini bertujuan untuk mengetahui faktor-faktor yang berhubungan dengan kejadian abortus di Indonesia. Penelitian ini dilaksanakan dengan metode observasional menggunakan disain studi cross sectional. Data penelitian diperoleh dari data Survei Demografi dan Kesehatan Indonesia 2002-2003. Analisis data dilakukan secara bertahap yaitu: analisis univariat, analisis bivariat dan analisis multivariat dengan regresi logistik. Hasil menunjukkan bahwa risiko abortus meningkat seiring dengan peningkatan usia ibu. Wanita dengan paritas $0-2$ berisiko lebih tinggi untuk mengalami abortus dibandingkan wanita dengan paritas 3 atau lebih $(O R=5,2$, IK 95\%=3,49-7,89). Wanita yang bekerja berisiko 2,7 kali lebih tinggi untuk mengalami aborsi daripada wanita yang tidak bekerja (OR=2,7, IK 95\%=2,10-3,58). Selain itu, risiko abortus meningkat pada wanita yang menikah pada usia 30 tahun atau lebih $(\mathrm{OR}=1,8, \mathrm{IK} 95 \%=1,30-2,48)$. Risiko abortus tidak berhubungan bermakna dengan riwayat abortus sebelumnya, tingkat pendidikan dan tingkat sosial ekonomi.
\end{abstract}

Kata kunci : Abortus, tren abortus, determinan abortus, Indonesia

\begin{abstract}
Abortion has become a main problem in public health because of its impact on maternal morbidity and mortality. There is no comprehensive data on abortion in Indonesia. So far, data were based on survey with limited coverage. Unsafe abortion is responsible to 11 percent of maternal mortality in Indonesia. This research objective is to determine factors related to abortion in Indonesia. The study was an observational method with cross sectional design. These data are gathered from Indonesian Demography and Health Survey 2002-2003. Data analysis used univariate, bivariate and multivariate analysis with logistic regression. The risk of an abortion increased in line with the increasing of maternal age. Women with $0-2$ parity have higher risk than multiparity (OR=5.2, IK95\%=3.49-7.89). Employed women have higher risk than unemployed ( $\mathrm{OR}=2.7$, IK95\%=2.10-3.58). The risk of abortion increased among women married at 30 years old or over $(\mathrm{OR}=1.8, \mathrm{IK} 95 \%=1.30-2.48)$. There is no significant association between history of abortion, education, socioeconomic and risk of abortion.

Key words : Abortion, trend of abortion, abortion's determinant, Indonesia


Abortus adalah kejadian produk konsepsi yang keluar sebelum usia kehamilan 20 minggu. Abortus spontan adalah abortus yang terjadi secara spontan tanpa ada unsur kesengajaan. Abortus disengaja (induced abortion) adalah abortus yang terjadi karena tindakan yang sengaja dilakukan untuk mengakhiri kehamilan sebelum usia 20 minggu. ${ }^{1}$ WHO menetapkan bahwa abortus termasuk dalam masalah kesehatan reproduksi yang perlu mendapatkan perhatian dan merupakan penyebab penderitaan wanita di seluruh dunia. Masalah abortus mendapat perhatian penting dalam kesehatan masyarakat karena berpengaruh terhadap morbiditas dan mortalitas maternal. Setiap tahun, diperkirakan terjadi 79 juta kehamilan yang tidak diinginkan (unintended pregnancy). Lebih dari setengah kehamilan tersebut berakhir dengan abortus. ${ }^{1}$ Abortus spontan merupakan penyebab terbanyak fetal loss. Delapan puluh persen fetal loss disebabkan oleh abortus spontan. ${ }^{2}$ Sekitar $10-15 \%$ kehamilan berakhir dengan abortus spontan pada usia kehamilan antara bulan kedua dan kelima. Sekitar setengahnya disebabkan oleh anomali kromosom pada embrio. ${ }^{3}$

Pada 1995, angka abortus di seluruh dunia adalah sekitar 35 per 1000 wanita yang berusia 15-44 tahun. Dari seluruh kehamilan (selain keguguran dan lahir mati), 26\% berakhir dengan abortus. Sekitar $44 \%$ abortus di dunia adalah ilegal, 64\% abortus legal dan hampir 95\% abortus ilegal terjadi di negara berkembang. ${ }^{1,4}$ Setiap tahun, sekitar 500.000 ibu meninggal karena sebab - sebab yang berkaitan dengan kehamilan. Sebagian besar kematian terjadi di negara berkembang dan sebagian disebabkan oleh abortus yang tidak aman. Sekitar 25\% kematian ibu di Asia, 30-50\% kematian ibu di Afrika dan Amerika Latin disebabkan oleh abortus yang disengaja. ${ }^{1}$ Di Myanmar, meskipun angka kematian ibu terus mengalami penurunan, kematian ibu karena abortus masih tetap tinggi. Berdasarkan hasil penelitian perspektif pada tahun 1983 di seluruh rumah sakit spesialis, komplikasi abortus (baik spontan maupun induced) bertanggung jawab terhadap sekitar 50\% kematian ibu. Penyebab kematian utama adalah peritonitis umum dan septikemia. ${ }^{5}$

Berdasarkan kondisi tempat pelaksanaan abortus dan metode yang digunakan, berbagai komplikasi berat dapat terjadi. Komplikasi seperti sepsis, perdarahan, trauma genital dan abdominal, perforasi uterus atau keracunan dapat berakibat fatal apabila terlambat ditangani. Kematian juga dapat merupakan komplikasi sekunder dari gangren atau gagal ginjal akut. ${ }^{6}$ Setengah dari abortus tidak aman dunia terjadi di Asia, sepertiganya terjadi di Asia Tengah Selatan yang juga mempunyai angka kematian ibu terkait abortus yang besar, sekitar 29.000 kematian per tahun. Angka abortus tidak aman di Asia Tengah Selatan dan Asia Tenggara hampir sama besar sekitar 20 per 1000 wanita usia reproduktif.
Diperkirakan hampir 3 juta abortus tidak aman terjadi di Asia Tenggara dan menyebabkan 8000 ibu meninggal. ${ }^{6}$

Sampai saat ini, data yang komprehensif tentang kejadian abortus di Indonesia belum ada. Berbagai data yang diungkapkan adalah berdasarkan survei dengan cakupan yang relatif terbatas. Diperkirakan tingkat abortus di Indonesia adalah sekitar 2 sampai dengan 2,6 juta kasus per tahun, atau 43 abortus untuk setiap 100 kehamilan. Diperkirakan pula bahwa $30 \%$ di antara abortus tersebut dilakukan oleh penduduk usia 15-24 tahun. Data SDKI yang mencakup perempuan kawin usia 15-49 tahun menemukan bahwa tingkat abortus pada tahun 1997 diperkirakan 12\% dari seluruh kehamilan yang terjadi. Angka tersebut tidak jauh berbeda dengan hasil analisa data Survei Demografi dan Kesehatan Indonesia 2002-2003. ${ }^{7}$

Abortus yang tidak aman diperkirakan bertanggung jawab terhadap $11 \%$ kematian ibu di Indonesia (rata- rata dunia $13 \%$ ). Kematian tersebut sebenarnya dapat dicegah jika perempuan mempunyai akses terhadap informasi dan pelayanan kontrasepsi serta akses yang baik terhadap perawatan komplikasi abortus. Data dari SDKI 2002-2003 menunjukkan bahwa sekitar 7,2\% kelahiran yang terjadi tidak diinginkan. ${ }^{8}$

Beberapa peneliti telah melakukan penelitian tentang faktor risiko abortus spontan. Faktor- faktor tersebut antara lain meliputi peningkatan usia ibu dan ayah,2,3,9-12 merokok dan penggunaan kokain, ${ }^{13}$ kafein dan alkohol,13,14 serta riwayat abortus induksi pada kehamilan sebelumnya. ${ }^{15}$ Sementara itu, penelitian lain menunjukkan bahwa jumlah anggota keluarga, konsumsi kopi, jumlah kehamilan (gravidity), merokok dan riwayat abortus dalam keluarga merupakan faktor yang paling penting berkaitan dengan abortus pada berbagai kelompok usia. ${ }^{1}$ Penelitian ini bertujuan untuk mengetahui faktor yang berpengaruh terhadap kejadian abortus di Indonesia pada tahun 2002-2003.

\section{Metode}

Penelitian menggunakan desain observasional cross sectional. Sumber data yang digunakan adalah sumber data sekunder Survei Demografi dan Kesehatan Indonesia (SDKI) tahun 2002-2003 yang merupakan perluasan dari SDKI 1997, yang mencakup informasi tentang partisipasi pria berstatus kawin, istri dan anakanaknya dalam pemeliharaan kesehatan. ${ }^{8}$

Survei Demografi dan Kesehatan Indonesia (SDKI) 2002-2003 dilaksanakan di 26 propinsi di wilayah Indonesia. Survei ini tidak memasukkan responden dari propinsi Nanggroe Aceh Darussalam, Maluku, Maluku Utara dan Papua karena alasan keamanan. Populasi penelitian ini adalah wanita yang menjadi responden SDKI 2002-2003. Dari 34.738 rumah tangga yang terpilih dalam survei ini, 33.419 rumah tangga ditemukan, dan 
Tabel 1. Prevalensi Abortus di Indonesia Tahun 2002-2003

\begin{tabular}{|c|c|c|c|c|}
\hline Variabel & Katagori & Kasus Abortus & Populasi & Prevalensi $(\%)$ \\
\hline \multirow[t]{5}{*}{ Usia } & $<20$ tahun & 21 & 269 & 7,80 \\
\hline & 20-24 tahun & 54 & 878 & 6,15 \\
\hline & 25-29 tahun & 67 & 974 & 6,88 \\
\hline & 30-34 tahun & 61 & 720 & 8,47 \\
\hline & $\geq 35$ tahun & 77 & 560 & 13,75 \\
\hline \multirow[t]{2}{*}{ Paritas } & $0-2$ & 204 & 2152 & 9,48 \\
\hline & $\geq 3$ & 76 & 1251 & 6,08 \\
\hline \multirow[t]{2}{*}{ Riwayat Abortus } & ya & 28 & 232 & 12,07 \\
\hline & tidak & 252 & 3169 & 7,95 \\
\hline \multirow[t]{2}{*}{ Pekerjaan } & Bekerja & 149 & 1082 & 13,77 \\
\hline & Tidak bekerja & 131 & 2319 & 5,65 \\
\hline \multirow[t]{4}{*}{ Tingkat Pendidikan } & $<$ SLTP & 9 & 127 & 7,09 \\
\hline & SLTP & 103 & 1441 & 7,15 \\
\hline & SLTA & 134 & 1563 & 8,57 \\
\hline & Sarjana & 34 & 379 & 8,97 \\
\hline \multirow[t]{4}{*}{ Usia Menikah } & $<20$ tahun & 148 & 1823 & 6,09 \\
\hline & 20-24 tahun & 89 & 1120 & 7,94 \\
\hline & 25-29 tahun & 32 & 379 & 8,44 \\
\hline & $\geq 30$ tahun & 11 & 73 & 15,09 \\
\hline \multirow[t]{5}{*}{ Sosial Ekonomi } & Sangat miskin & 64 & 1060 & 6,04 \\
\hline & Miskin & 43 & 642 & 6,69 \\
\hline & Menengah & 55 & 575 & 9,56 \\
\hline & Kaya & 59 & 524 & 11,26 \\
\hline & Sangat kaya & 59 & 6000 & 0,98 \\
\hline
\end{tabular}

Sumber: Analisis Data SDKI 2002-2003

dari jumlah tersebut 33.088 atau 99\% rumah tangga berhasil diwawancarai. Dalam rumah tangga yang diwawancarai, ada 29.996 wanita yang memenuhi syarat untuk diwawancarai, dan yang berhasil diwawancarai adalah 29.483 orang atau $98 \%$ dari wanita yang memenuhi syarat. Sampel diseleksi sesuai dengan kriteria inklusi dan kriteria eksklusi yang ditentukan. Kriteria inklusi penelitian ini adalah berusia 15-49 tahun, belum menopause/mengalami histerektomi, mengeluarkan produk konsepsi pada tahun 2002, baik berupa abortus, melahirkan ataupun stillbirth.

Data yang dilakukan analisis bivariabel dan multivariabel adalah data wanita yang mengeluarkan produk konsepsi baik berupa kelahiran ataupun abortus pada tahun 2002. Batasan abortus pada penelitian ini adalah kejadian produk konsepsi keluar sebelum usia kehamilan lima bulan oleh sebab apapun yang dilaporkan oleh responden. Peneliti tidak memisahkan apakah abortus yang dialami responden adalah abortus spontan atau induksi, aman atau tidak aman, karena data hasil SDKI memang tidak spesifik menjelaskan jenis abortus yang dialami responden. Analisis multivariabel dilakukan untuk mengukur secara bersama-sama variabel terikat, variabel bebas dan variabel luar dengan menggunakan uji regresi lo- gistik. Analisis menggunakan program Stata 9.

\section{Hasil}

Prevalensi

Dengan jumlah kasus abortus $=280$ dan populasi $=$ 3401 maka prevalensi abortus adalah $=8,23 \%$. Kasus abortus paling tinggi pada: kelompok usia 35 tahun atau lebih, $(13,75 \%)$; kelompok paritas 0-2 $(9,48 \%)$, yang pernah mengalami abortus sebelumnya $(12,07 \%)$; wanita bekerja $(13,77 \%)$ yang berpendidikan sarjana $(8,97 \%)$; usia menikah $\geq 30$ tahun $(15,09 \%)$; sosial ekonomi kaya $(11,29 \%)$ (Lihat Tabel 1).

\section{Analisa Multivariat}

Analisis multivariat dilakukan untuk melihat hubungan variabel bebas, variabel terikat dan variabel pengganggu secara bersama-sama. Uji statistik yang digunakan adalah uji regresi logistik. Pada tingkat kemaknaan $\mathrm{p}<0,05$. Kekuatan hubungan dilihat dari nilai OR dengan tingkat kepercayaan 95\%. Hasil analisis multivariat selengkapnya dapat dilihat pada Tabel 2.

Analisis menggunakan pemodelan berikut: Model 1 menjelaskan hubungan variabel bebas (usia, paritas, riwayat abortus sebelumnya) dengan abortus. Terlihat 
Tabel 2. Hasil Analisis Multivariabel dengan Pemodelan Regresi Logistik tentang Abortus di Indonesia Tahun 2002

\begin{tabular}{|c|c|c|c|c|c|c|}
\hline Variabel & $\begin{array}{c}\text { Model } 1 \\
\text { OR (IK 95\%) }\end{array}$ & $\begin{array}{c}\text { Model } 2 \\
\text { OR (IK95\%) }\end{array}$ & $\begin{array}{c}\text { Model } 3 \\
\text { OR (IK95\%) }\end{array}$ & $\begin{array}{c}\text { Model } 4 \\
\text { OR (IK 95\%) }\end{array}$ & $\begin{array}{c}\text { Model } 5 \\
\text { OR (IK95\%) }\end{array}$ & $\begin{array}{c}\text { Model } 6 \\
\text { OR (IK95\%) }\end{array}$ \\
\hline \multicolumn{7}{|l|}{ Usia } \\
\hline 15-19 tahun & $1,2(0,73-2,09)$ & $1,3(0,76-2,18)$ & $1,3(0,75-2,13)$ & $1,1(0,63-1,83)$ & $1,3(0,77-2,20)$ & $1,2(0,68-1,99)$ \\
\hline 20-24 tahun & 1 (referensi) & 1 (referensi) & 1 (referensi) & 1 (referensi) & 1 (referensi) & 1 (referensi) \\
\hline $25-29$ tahun & $1,4(0,94-1,98)$ & $1,3(0,86-1,83)$ & $1,3(0,92-1,95)$ & $1,7(1,17-2,54)^{* * * *}$ & $1,3(0,91-1,93)$ & $1,6(1,09-2,40) *$ \\
\hline 30-34 tahun & $2,4(1,61-3,57)^{* * *}$ & $1,9(1,29-2,91)^{* *}$ & $2,3(1,54-3,47)^{* * *}$ & $3,7(2,38-5,78)^{* * * *}$ & $2,3(1,53-3,45)^{* * *}$ & $3,1(1,94-4,83)^{* * *}$ \\
\hline \multicolumn{6}{|l|}{ Paritas } & $8,4(5,00-14,23) * *$ \\
\hline $0-2$ & $3,6(2,60-5,12)^{* * *}$ & $3,6(2,56-5,07)^{* * *}$ & $3,5(2,44-4,92)^{* *}$ & $5,5(3,72-8,23)^{* * * *}$ & $3,4(2,40-4,79)^{* * *}$ & $5,2(3,49-7,89)^{* *}$ \\
\hline$\geq 3$ & 1 (referensi) & 1 (referensi) & 1 (referensi) & 1 (referensi) & 1 (referensi) & 1 (referensi) \\
\hline \multicolumn{7}{|l|}{ Riwayat Abortus } \\
\hline Ya & $1,4(0,89-2,13)$ & $1,4(0,89-2,14)$ & $1,4(0,88-2,09)$ & $1,4(0,89-2,13)$ & $1,3(0,88-2,09)$ & $1,3(0,86-2,01)$ \\
\hline Tidak & 1 (referensi) & 1 (referensi) & 1 (referensi) & 1 (referensi) & 1 (referensi) & 1 (referensi) \\
\hline \multicolumn{7}{|l|}{ Pekerjaan } \\
\hline Bekerja & & $2,5(1,91-3,20)^{* * *}$ & & & & $2,7(2,10-3,58)^{* * *}$ \\
\hline Tidak bekerja & & 1 (referensi) & & & & 1 (referensi) \\
\hline \multicolumn{7}{|l|}{ Pendidikan } \\
\hline Tidak berpendidikan & & & $0,7(0,33-1,64)$ & & & $0,7(0,31-1,83)$ \\
\hline Primer & & & $0,8(0,53-1,27)$ & & & $0,7(0,43-1,260$ \\
\hline Sekunder & & & $0,9(0,61-1,41)$ & & & $0,9(0,54-1,37)$ \\
\hline Lebih tinggi & & & 1 (referensi) & & & 1 (referensi) \\
\hline \multicolumn{7}{|l|}{ Usia Menikah } \\
\hline$<20$ tahun & & & & 1 (referensi) & & 1 (referensi) \\
\hline 20-24 tahun & & & & $0,6(0,40-0,98) *$ & & $0,6(0,36-0,91)^{*}$ \\
\hline 25-29 tahun & & & & $0,5(0,23-1,02)$ & & $0,4(0,20-0,91)^{*}$ \\
\hline$\geq 30$ tahun & & & & $1,5(1,10-2,02)^{*}$ & & $1,8(1,30-2,48)^{* *}$ \\
\hline \multicolumn{7}{|l|}{ Sosial Ekonomi } \\
\hline Sangat miskin & & & & & $0,8(0,54-1,17)$ & $0,7(0,46-1,13)$ \\
\hline Miskin & & & & & $0,9(0,57-1,32)$ & $0,9(0,57-1,44)$ \\
\hline Menengah & & & & & $1,2(0,79-1,76)$ & $1,3(0,85-2,01)$ \\
\hline Kaya & & & & & $1,4(0,92-2,01)$ & $1,4(0,90-2,06)$ \\
\hline Sangat kaya & & & & & 1 (referensi) & 1 (referensi) \\
\hline $\mathrm{N}$ & 3401 & 3401 & 3401 & 3401 & 3401 & 3401 \\
\hline Pseudo $\mathrm{R}^{2}(\%)$ & 4,6 & 7,1 & 4,7 & 5,1 & 5,1 & 9,3 \\
\hline LR Chi2 (df) & 90,04 & 137,57 & 91,41 & 99,51 & 99,51 & 179,81 \\
\hline Log Likehood & $-922,29$ & $-898,53$ & $-921,61$ & $-917,56$ & $-917,56$ & $-877,41$ \\
\hline
\end{tabular}

Sumber: Analisis Data SDKI 2002-2003

Keterangan: * signifikansi <0,05, $* *$ signifikansi $<0,01$

bahwa risiko abortus meningkat secara bermakna pada usia 30-34 tahun $(\mathrm{OR}=2,4$; IK95\%=1,61-3,57) dan usia 35 tahun atau lebih $(\mathrm{OR}=5,9$; IK95\%=3,83-9,13) dibandingkan wanita usia 20-24 tahun. Risiko abortus juga meningkat pada usia kurang dari 20 tahun, tetapi tidak bermakna secara statistik $(\mathrm{OR}=1,2$; IK95\%=0,732,09). Model ini juga memperlihatkan bahwa risiko abortus berhubungan bermakna dengan paritas. Wanita dengan paritas $0-2$ berisiko abortus lebih tinggi daripada wanita dengan paritas 3 atau lebih (OR= 3,6; IK95\% $2,60-5,12)$. Riwayat abortus sebelumnya cenderung meningkatkan risiko abortus meskipun tidak bermakna secara statistik $(\mathrm{OR}=1,4$; IK95\%=0,89-2,13). Pada model 1 ini, kemampuan variabel bebas memprediksi variabel terikat adalah $4,6 \%$ (Lihat Tabel 2).

Model 2 yang melibatkan variabel pekerjaan memperlihatkan risiko abortus tetap meningkat secara bermakna pada usia 30-34 tahun $(\mathrm{OR}=1,9$; IK95\%= 1,29-2,91) dan usia 35 tahun atau lebih $(\mathrm{OR}=4,7$;
IK95\% = 3,03-7,35) daripada wanita usia 20-24 tahun dengan nilai OR yang lebih rendah daripada hasil analisis model 1. Risiko abortus meningkat sesuai dengan peningkatan umur, kecuali pada wanita hamil berusia kurang dari 20 tahun berisiko abortus lebih tinggi daripada usia 20-24 tahun. Risiko abortus berhubungan secara bermakna dengan paritas. Wanita dengan paritas 0-2 berisiko abortus lebih tinggi daripada wanita dengan paritas 3 atau lebih $(\mathrm{OR}=3,6$; IK95\% 2,56-5,07). Riwayat abortus sebelumnya cenderung meningkatkan risiko abortus, tetapi tidak bermakna secara statistik $(\mathrm{OR}=1,4$; IK95\%= 0,89-2,15). Wanita hamil yang bekerja berisiko abortus lebih tinggi daripada yang tidak bekerja $(\mathrm{OR}=$ 2,5; IK95\% = 1,91-3,20). Pada model 2, kemampuan variabel bebas dalam memprediksi variabel terikat adalah sebesar 7,1\% (Lihat Tabel 2).

Model 3 yang melibatkan variabel pendidikan memperlihatkan risiko abortus meningkat secara bermakna pada usia 30-34 tahun $(\mathrm{OR}=2,3$; IK95\%=1,54-3,47) 
dan usia 35 tahun atau lebih $(\mathrm{OR}=5,8$; IK95\%=3,75$9,08)$ daripada wanita usia 20-24 tahun. Nilai OR tersebut sedikit lebih rendah daripada hasil analisis model 1 . Risiko abortus meningkat sesuai dengan peningkatan umur, kecuali pada wanita hamil berusia kurang dari 20 tahun berisiko abortus lebih tinggi daripada usia 20-24 tahun, tetapi tidak bermakna. Risiko abortus berhubungan bermakna dengan paritas. Wanita dengan paritas 02 berisiko abortus lebih tinggi daripada wanita dengan paritas 3 atau lebih $(\mathrm{OR}=3,5$; IK95\%=2,44-4,92) meskipun OR sedikit lebih rendah dibandingkan analisis model 1. Riwayat abortus cenderung meningkatkan risiko abortus meskipun tidak bermakna secara statistik $(\mathrm{OR}=1,3$; IK95\%= 0,88-2,09). Tidak ada hubungan yang bermakna antara risiko abortus dengan tingkat pendidikan. Pada model 3, kemampuan variabel bebas memprediksi variabel terikat adalah 4,7\% (Lihat Tabel 2).

Model 4 memperlihatkan bahwa risiko abortus meningkat secara bermakna pada wanita hamil pada usia usia 25-29 tahun $(\mathrm{OR}=1,7$; IK95\%=1,17-2,54), 30-34 tahun $(\mathrm{OR}=3,7$; IK95\%=2,38-5,78) dan usia 35 tahun atau lebih $(\mathrm{OR}=10,0 ; \mathrm{IK} 95 \%=6,06-16,64)$ daripada usia 20-24 tahun. Risiko abortus meningkat sesuai dengan peningkatan umur, kecuali pada wanita hamil berusia kurang dari 20 tahun berisiko abortus lebih tinggi daripada usia 20-24 tahun, meskipun secara statistik tidak bermakna. Nilai OR model 4 ini lebih tinggi daripada OR hasil analisis model 1. Risiko abortus juga berhubungan bermakna dengan paritas, wanita dengan paritas 0 2 berisiko abortus lebih tinggi daripada paritas 3 atau lebih $(\mathrm{OR}=5,5$; IK95\% 3,72-8,24). Nilai OR pada analisis ini lebih tinggi dibandingkan analisis secara statistik tidak bermakna $(\mathrm{OR}=1,4$; IK95\%=0,89-2,13). Semakin bertambah usia saat menikah, semakin meningkat risiko abortus. Peningkatan risiko ini bermakna pada wanita yang menikah pada usia 30 tahun ke atas $(O R=1,5$; IK95\% $=1,10-2,02$ ). Pada model 4 , kemampuan variabel bebas dalam memprediksi variabel terikat adalah sebesar 5,6\% (Lihat Tabel 2).

Model 5 memperlihatkan risiko abortus yang meningkat secara bermakna pada kelompok usia 30-34 tahun dan kelompok usia 35 tahun atau lebih daripada usia 20-24 tahun. Risiko abortus meningkat sesuai dengan peningkatan umur, kecuali pada usia kurang dari 20 tahun, risiko abortus lebih tinggi daripada usia 20-24 tahun. Risiko abortus juga berhubungan secara bermakna dengan paritas, wanita dengan paritas $0-2$ berisiko abortus lebih tinggi daripada paritas 3 atau lebih $(\mathrm{OR}=$ 3,4, IK95\% 2,40-4,79). Nilai OR menjadi lebih rendah daripada hasil analisis model 1. Riwayat abortus cenderung meningkatkan risiko abortus meskipun secara statistik tidak bermakna $(\mathrm{OR}=1,3$, IK95\%=0,88-2,09). Risiko kejadian abortus tidak berhubungan bermakna dengan tingkat sosial ekonomi. Pada model 5, kemam- puan variabel bebas memprediksi variabel terikat adalah $5,1 \%$ (Lihat Tabel 2).

Model 6 yang melibatkan semua variabel pengganggu, meliputi pekerjaan, pendidikan, usia nikah dan sosial ekonomi. Model ini memperlihatkan risiko abortus yang meningkat secara bermakna pada kelompok usia 30-34 tahun dan usia 35 tahun ke atas, daripada usia 20-24 tahun. Risiko abortus meningkat sesuai dengan peningkatan umur, kecuali pada wanita berusia kurang dari 20 tahun yang berisiko abortus lebih tinggi daripada usia 20-24 tahun. Wanita dengan paritas 0-2 berisiko abortus lebih tinggi untuk daripada wanita dengan paritas 3 atau lebih $(\mathrm{OR}=5,2$; IK95\% 3,49-7,89). Riwayat abortus cenderung meningkatkan risiko abortus tetapi secara statistik tidak bermakna $(\mathrm{OR}=1,3$; IK95\%=0,86-2,07). Wanita bekerja berisiko lebih tinggi daripada yang tidak bekerja. Risiko abortus meningkat pada wanita yang menikah pada usia 30 tahun atau lebih. Tidak ada hubungan yang bermakna antara abortus dengan tingkat pendidikan dan status sosial ekonomi. Pada analisis model 6, kemampuan variabel bebas dalam memprediksikan variabel terikat adalah 9,3\% (Lihat Tabel 2).

Hasil analisis model 1 sampai model 6, dapat disimpulkan bahwa risiko abortus meningkat sesuai dengan peningkatan usia ibu, kecuali ibu berusia kurang dari 20 tahun berisiko lebih tinggi daripada usia 20-24 tahun. Risiko abortus juga meningkat pada wanita dengan paritas 0-2, wanita yang bekerja serta wanita yang menikah pada usia 30 tahun atau lebih. Risiko abortus tidak berhubungan bermakna dengan riwayat abortus sebelumnya, tingkat pendidikan dan tingkat sosial ekonomi (Lihat Tabel 2).

\section{Pembahasan}

Secara umum, ada dua penyebab abortus spontan yaitu ovofetal dan maternal. ${ }^{16}$ Pada minggu- minggu pertama (0-10 minggu) faktor ovofetal bertanggungjawab atas sebagian besar abortus, pada kehamilan selanjutnya (11-22 minggu) faktor ibu menjadi lebih umum. Pemeriksaan USG dan histologik menunjukkan bahwa pada $70 \%$ kasus, ovum yang telah dibuahi gagal berkembang dan mengalami malformasi. Pada $40 \%$ kasus ini, kelainan kromosom mendasari terjadinya abortus. Penyakit sistemik pada ibu, terutama infeksi, bertanggungjawab terhadap 2\% abortus. Sebanyak $8 \%$ berhubungan dengan kelainan uterus. Penyebab psikosomatik diduga merupakan penyebab $15 \%$ abortus, tetapi hal tersebut sulit untuk dibuktikan.

Berdasarkan hasil analisis multivariabel dapat disimpulkan bahwa risiko kejadian abortus di Indonesia berhubungan bermakna dengan usia ibu, paritas dan pekerjaan ibu. Risiko abortus meningkat sesuai dengan peningkatan usia ibu, kecuali bahwa usia ibu kurang dari 20 tahun lebih tinggi risikonya dibandingkan usia 20-24 
tahun. Hasil penelitian ini sesuai dengan hasil penelitian Nybo Andersen, ${ }^{2}$ yang menunjukkan bahwa usia maternal merupakan faktor risiko yang kuat dan independen terhadap kejadian fetal loss (termasuk abortus). Alasan utama hubungan usia ibu dengan fetal loss ini adalah peningkatan risiko konsepsi aneuploidi seiring dengan peningkatan usia ibu dan fakta bahwa konsepsi aneuploidi lebih sering menimbulkan fetal loss.

Peningkatan risiko konsepsi aneuploidi ini merupakan konsekuensi dari panjangnya waktu istirahat meiotik pada oocyte primer antara profase meiotik pertama pada bulan kelima kehidupan fetal sampai terbentuknya oocyte beberapa dekade kemudian. Pada nulipara peningkatan usia dengan waktu menanti kehamilan pertama yang lama merujuk pada adanya subfertilitas. Penelitian terdahulu menunjukkan bahwa subfertilitas merupakan faktor risiko kejadian abortus. Pada kelompok wanita yang memiliki anak, grande multipara lebih banyak pada ibu dengan usia lebih tua. Diketahui bahwa grande multipara merupakan faktor risiko abortus.2,11 Selain itu, cakupan pemeriksaan kehamilan di Indonesia sedikit lebih rendah untuk ibu berusia 35 tahun ke atas yang lebih cenderung pergi ke dukun atau lebih cenderung tidak memeriksakan kehamilannya. ${ }^{8}$ Peningkatan usia maternal akan meningkatkan risiko konsepsi aneuploidi dan hal tersebut akan meningkatkan risiko terjadinya abortus. ${ }^{11}$ Pengaruh negatif peningkatan usia ibu terhadap outcome kehamilan dapat dinilai dari menurunnya fertilitas, keguguran, abnormalitas kromosom, komplikasi hipertensi dan stillbirth. ${ }^{17}$ Peningkatan usia ayah akan meningkatkan risiko terjadinya mutasi spontan pada spermatozoa yang akan mengawali terjadinya single gene mutation. 3,11

Risiko abortus juga meningkat pada wanita dengan paritas 0-2, wanita yang bekerja serta wanita yang menikah pada usia 30 tahun atau lebih. Hal ini sesuai dengan hasil penelitian di Mesir. ${ }^{18}$ Risiko abortus paling tinggi pada wanita dengan paritas 0 atau pada kehamilan pertama. Hal tersebut berkaitan dengan kesiapan fisik dan psikis ibu pada kehamilan pertama yang relatif belum matang. Angka abortus berdasarkan paritas paling tinggi pada kelompok wanita dengan paritas 0 (nulipara) dan kembali meningkat pada grande multipara.

Wanita hamil yang bekerja berisiko untuk mengalami abortus lebih tinggi dibanding yang tidak bekerja. Hal ini mungkin disebabkan oleh beban ganda ibu rumah tangga sekaligus sebagai wanita karier. Nutrisi selama kehamilan, beban pekerjaan pada wanita hamil dan perencanaan kehamilan. Beban kerja yang berlebihan, terutama berdiri lebih dari 5 jam per hari merupakan faktor risiko independen kelahiran pre-term dan IUGR (Intra Uterine Growth Retardation). Hasil penelitian ini sesuai dengan hasil penelitian sebelumnya. ${ }^{18}$ Usia saat menikah ternyata juga berhubungan dengan risiko abortus, ini mungkin terkait dengan usia ibu saat mengalami kehamilan nantinya. Berdasarkan analisis multivariat didapatkan bahwa usia aman untuk menikah adalah 20 sampai 29 tahun, risiko abortus lebih tinggi pada usia kurang dari 20 tahun dan lebih dari 30 tahun.

Risiko abortus tidak berhubungan bermakna dengan riwayat abortus sebelumnya, tingkat pendidikan dan tingkat sosial ekonomi. Secara teoritis, status sosial ekonomi ditentukan oleh tingkat pendidikan dan pekerjaan dan akan berpengaruh terhadap kesempatan keluarga untuk mendapatkan pelayanan kesehatan yang optimal termasuk dalam hal ini ANC dan pelayanan keluarga berencana. ${ }^{19}$ Sebab mendasar kematian fetal-neonatal antara lain status gizi wanita yang rendah, pernikahan usia muda, tingginya fertilitas, dan tingkat pendidikan yang rendah. Usia pernikahan yang terlalu muda akan membatasi kesempatan untuk mendapatkan pendidikan dan status ekonomi serta menyebabkan kehamilan usia muda.

\section{Kesimpulan}

Simpulan dari penelitian ini adalah risiko abortus berhubungan dengan usia ibu, paritas, pekerjaan ibu dan usia ibu saat menikah. Semakin bertambah usia ibu, semakin tinggi risiko untuk mengalami abortus. Berdasarkan paritas, wanita dengan paritas 0-2 berisiko lebih tinggi untuk mengalami abortus dibandingkan wanita dengan paritas 3 atau lebih $(\mathrm{OR}=5,2$; IK95\%=3,49-7,89). Wanita yang bekerja berisiko lebih tinggi dibandingkan wanita yang tidak bekerja $(\mathrm{OR}=2,7$; IK $95 \%=2,10-3,58)$. Selain itu, risiko abortus meningkat pada wanita yang menikah pada usia 30 tahun atau lebih $(\mathrm{OR}=1,8 ; \mathrm{IK} 95 \%=1,30-2,48)$. Risiko abortus tidak berhubungan bermakna dengan riwayat abortus sebelumnya, tingkat pendidikan dan tingkat sosial ekonomi.

\section{Saran}

Penelitian ini merupakan penelitian abortus pertama di Indonesia dengan data yang cukup banyak dan skala yang luas (nasional). Beberapa intervensi yang perlu terus dilakukan untuk menekan angka abortus antara lain melalui mengoptimalkan program KB termasuk penyebarluasan informasi mengenai usia aman untuk hamil dan melahirkan serta jumlah anak yang ideal. Perlu juga dipertimbangkan adanya cuti hamil untuk wanita yang bekerja, terutama pada trimester pertama yang rentan terhadap kejadian abortus

\section{Daftar Pustaka}

1. Nojomi M, Akbarian A, Ashory-Moghadam S. Burden of abortion: induced and spontaneous. Arch Iranian Med. 2006; 9: 39-45.

2. Nybo-Anderson AM, Wohlfahrt J, Christens P, Olsen J, Melbye M. Maternal age and fetal loss: population-based register linkage study. 
BMJ. 2000; 320: 1708 - 12.

3. Slama R, Werwatz A, Boutou O, Ducot B, Spira A, Hardle W. Does male age affect the risk of spontaneous abortion? an approach using semimetric regression. Am J Epidemiol. 2003; 157: 815-24.

4. Henshaw SK, Singh S, Haas T. The incidence of abortion worldwide. Int Fam Plan Perspect. 1999; 25: S30-S38.

5. Ba-Thike K. Abortion: a public health problem in Myanmar. Reprod Health Matters. 1997; 9: 94-100.

6. World Health Organization. Unsafe abortion: global and regional estimates of incidence of and mortality due to unsafe abortion with a listing of available country data. Third Edition. Geneva: Division of Reproductive Health (Technical Support) WHO; 1998. WHO/RHT/MSM/97.16-1997.

7. Wilopo SA. Makalah kunci. Seminar kita selamatkan remaja dari abortus dalam rangka pemantapan keluarga berkualitas 2015. Medan, 11 April 2005.

8. BPS, BKKBN, Depkes, DHS. Survei demografi dan kesehatan 20022003. Calverton, Maryland: Biro Pusat Statistik, Badan Koordinasi Keluarga Berencana, Departemen Kesehatan, dan Macro International; 2003.

9. De La Rochebrochard E, Mcelreavey K, Thonneau P. Paternal age over 40 Years: The "amber light" in the reproductive life of men? J Androl. 2003; 24: 459-65.

10. De La Rochebrochard E, Thonneau P. Paternal age and maternal age are risk factors for miscarriage; results of multicentre European study. Hum
Reprod. 2002; 17: 1649-56.

11. Nybo Andersen AM, Hansen KD, Andersen PK, Smith GD. Advanced paternal age and risk of fetal death: a cohort study. Am J Epidemiol. 2004; 160: 1214-22.

12. Ness RB, Grisso JA, Hirschinger N, Markovic N, ShawLM, Day NL, Kline J. Cocaine and tobacco and the risk of spontaneous abortion. N Engl J Med. 1999; 340: 333-9.

13. Tolstrup JS, Kjaer SK, Munk C, Madsen LB, Ottesen B, Bergholt T, et al. Does caffeine and alcohol intake before pregnancy predict the occurence of spontaneous abortion? Hum Reprod. 2003;18: 2704-10.

14. Kesmodel U, Wisborg K, Olsen SF, Henriksen TB, Secher NJ. Moderate alcohol intake in pregnancy and the risk of spontaneous abortion. Alcohol Alcohol. 2002; 37: 87-92.

15. Sun Y, Che Y, Gao E, Olsen J, Zhou W. Induced abortion and risk of subsequent miscarriage. Int J Epidemiol. 2003; 32: 449-54.

16. Llewellyn-Jones D. Fundamentals of obstetrics and gynaecology. Edisi ke-6. Edisi Bahasa Indonesia. Jakarta: Hipokrates; 2001.

17. Heffner LJ. Advanced maternal age- how old is too old? N Engl J Med. 2004; 351; 19: 1927-29.

18. Yassin KM. Incidence and socioeconomic determinants of abortion in rural upper Egypt. Public Health. 2000; 114: 269-72.

19. Melki IS, Beydoun HA, Khogali M, Tamim H, Yunis KA. Household crowding index: a correlate of socioeconomic status and inter-pregnancy spacing in an urban setting. J Epidemiol Community Health. 2003; 58: $476-80$. 